\title{
Spiritualitas Pada Tokoh Novae Dalam Novel Hipernova Karya Fariza Auliya Jasmine
}

\author{
Ellif Shiffiyn Khairaa
}

Master Program of Literary and Cultural Studies, Faculty of Humanities Universitas Airlangga, Surabaya.Indonesia

\begin{tabular}{l} 
Article Info \\
\hline Article history: \\
Submitted Jan 25, 2020 \\
Revised April 14, 2020 \\
Accepted Aug 07, 2020 \\
Published November 2, 2020
\end{tabular}

\section{Keywords:}

Spirituality

Atheist

Semiotic

Barthes

Novel

\begin{abstract}
This study aims to reveal the spirituality of Novae personage in the novel entitled Hipernova by Fariza Auliya Jasmine. Novae is the main character of the novel. Novae is an atheist and become a moeslem after reading scrapbook that written by Hipernova. As an atheist Novae had a strong character and characterization seen by critical thinking and independent woman. She used to reflect her life through her cleverness. Therefore, this study used descriptive qualitative research. It is focused on describing the data or phenomenon found in the text. This study used structural narrative analysis by using five semiological Barthes to reveal the action that refers to the spiritual aspect of Novae. Data collection techniques is done by using the library research techniques. There are five semiological code found in this text; (1) hermeneutic (HER: the meaning behind the title of Hipernova), (2) Semes code (SEM: light, white) that refers to the character of Novae, (3) Symbolic code (SYM), it is found in scrapbook; atheism vs monotheism, religion as belief vs heritage religion, hope vs not hope to, (4) Cultural code consists of some knowledge of Islam, (REF: Quotation of Surah AL-Falaq in Al-Quran, hadist, and one of asmaul husna), (5) Proaretic code (ACT: work, bersyahadat, bersedekah) refers to an action that leads to spiritual action. Five semiological codes lead to the spirituality aspects found in Novae personage. There were critical thinking, idealism, transcendent aspect to Allah SWT, meaning and purpose of life, and fruits of spirituality. Those aspects explained the spirituality of Novae personage in the novel entitled Hipernova by Fariza Auliya Jasmine.
\end{abstract}

Corresponding Author:

Ellif Shiffiyn Khairaa,

Program Studi S2 Kajian Sastra dan Budaya, Pascasarjana Universitas Airlangga

Universitas Airlangga, Surabaya

Jl. Airlangga No. 4-6, Airlangga, kec. Gubeng, Kota Surabaya, Jawa Timur, Indonesia

Email: ellif.iffiyn.khairaa-2018@fib.unair.ac.id

\section{PENDAHULUAN}

Perkembangan dunia sastra yang saat ini seolah lebih terbuka dan cenderung mengarahkan masyarakat terhadap pandangan hidup yang dulunya dianggap tabu menjadi layak untuk ditulis dan dipasarkan seperti pada novel bertema religius. Novel religi yang kini sedang berkembang tak lepas dari kondisi dan situasi masyarakat Indonesia yang tengah mengalami fenomena peningkatan religiusitas. Hal tersebut ditunjukkan dengan adanya fenomena hijrah dan ustad yang memiliki banyak fans fanatik atau lebih dikenal dengan dai selebriti. Fenomena tersebut semakin menunjukkan 
eksistensinya ketika banyak selebriti atau idola masyarakat juga hijrah dan rajin mengikuti kajian bersama ustad selebriti tersebut. Hal tersebut menambah banyaknya masyarakat yang berhijrah dan mengikuti kajian (Awaliyah, 2019). Dalam era globalisasi ini, masyarakat-masyarakat agamis, makin menunjukkan identitasnya menghadapi dunia maju sekuler yang makin memarginalkan nilai-nilai agama. Menurut Brezinsky dalam bukunya "Out of Control", dalam masyarakat Barat, agama telah berhenti sebagai panduan tingkah laku manusia. Sebaliknya, dalam masyarakat maju di Indonesia, umat beragama mengharapkan nilai-nilai agama akan muncul kembali dengan format gerakan baru keagamaan sebagai panduan etika bangsa (Brzezinski, 1993). Fenomena tersebut ditujukan untuk mempersatukan bangsa demi mencapai keutuhan dan persatuan.

Melihat fenomena tersebut, karya sastra bertema religi kemudian membuka ruang dan menempatkan diri bagi beberapa kebenaran yang dianggap saling bertentangan. Sastrawan kemudian menyematkan makna pada karya sastranya yang berupa makna niatan (amanat) dan makna muatan (tema). Makna niatan (Jabrohim, 2002) yang dimaksud adalah makna yang dikehendaki oleh sastrawan sedangkan makna muatan adalah makna yang terdapat dalam struktur karya sastra itu sendiri. Kedua jenis makna karya sastra itu jelas bertolak belakang dari pengalaman-pengalaman sastrawan. Pengalaman itu bisa diperoleh dalam interaksi sosial maupun pengalaman religiusnya.

Pengalaman religius tersebut membawa sastrawan pada kesadaran spiritualitas. Seorang pengarang akan mempresentasikan gagasan mengenai spiritualitas melalui tokoh-tokoh rekaan yang dimunculkan dalam berbagai karakter dan konflik dalam karya sastra. Kepercayaan pengarang akan keberadaan sesuatu yang bersifat imanen mendorongnya untuk mengungkapkan kepercayaan tersebut dalam karya sastra seperti pada novel Hipernova karya Fariza Auliya Jasmine.

Penggambaran tokoh utama menjadi sorotan pada novel ini. Tokoh utama yaitu Novae, merupakan model terkenal penderita albino yang sudah lama berhenti mempercayai Tuhan. Sampai saat ini, orang yang tidak meyakini adanya Tuhan ateis berpandangan bahwa aturan-aturan agama yang ada cenderung mengekang prilaku mereka ateis dalam berpikir dan bertindak. Ateis berkeyakinan bahwa kepercayaan pada Tuhan hanya akan menghambat kemajuan hidup manusia (Yusuf, 2012). Ketidakpercayaan pada Tuhan tidak dapat diukur dengan spiritualitas yang ada pada manusia. Hal ini berdasar pada spiritualitas manusia tidak dapat diukur ilmiah atau dengan banyaknya ritual keagamaan yang dijalankan (Spencer, 2012).

Namun, hal berbeda ditunjukkan oleh Novae seperti yang tertulis pada Scrapbook milik tokoh Hipernova. Scrapbook yang ditulis oleh tokoh Hipernova tersebut berisi tentang catatan tentang kehidupan Novae selama lima tahun terahir. Scrapbook tersebut menjelaskan bagaimana Novae memiliki ide, gagasan, serta nilai-nilai religius dalam dirinya. Scrapbook kemudian ditemukan oleh Novae dan menjadi jalan Novae dalam menemukan dan memahami jati dirinya yang secara keseluruhan merujuk pada inti sebuah kehidupan yaitu spiritualitas. Cottingham memaparkan pentingnya spiritualitas dalam kehidupan, "So construed, both supporters and opponents of religion might agree that the loss of the spiritual dimension would leave our human existence radically impoverished" 
(Conttingham, 2005). Spiritualitas kemudian dipahami sebagai konsep yang berkaitan dengan praksis atau cara hidup bukan hanya sebuah teoritik dan doktrin semata.

Fokus dalam penelitian ini yaitu terdapat pada spiritualitas tokoh Novae dalam novel Hipernova karya Fariza Auliya Jasmine. Novel ini dapat mengungkap beberapa hal tabu tentang keyakinan terhadap Tuhan dan nilai-nilai kehidupan. Dan melawan pandangan bahwa ateis merupakan orang yang jauh dari tingkat spiritualitasnya. Melalui penggambaran tokoh utama yang ateis namun mengusung tema religi, novel ini mampu mendorong pembaca untuk mengubah cara pandangnya terhadap spiritualitas ateisme. Penelitian ini kemudian menjadi penting dilakukan sebagaimana fenomena spiritualitas masih menjadi hal tabu bagi masyarakat kini. Penggunaan tanda dan penanda yang ada pada teks melalui penggamabaran tokoh utama dan prilakunya menjadi acuan peneliti untuk menggunakan teori semiotik dari Roland Barthes.

Beberapa penelitian telah dilakukan dengan memanfaatkan lima semiologi Barthes dengan tujuan melihat makna di balik tanda yang ada pada sebuah karya sastra dilakukan oleh Yuliani pada Lelaki Terahir Yang Menangis Di Bumi dengan temuan semangat hidup tokoh Jiwa dalam berkarya (Yuliani, 2018). Penelitian yang dilakukan Rina dan Widowati pada karya novel Bait-Bait Multazam dengan memanfaatkan lima kode semiologi Barthes menemukan makna moral dan nilai moral yang ada pada karya (Widowati \& Octaviani, 2016). Pada penelitian oleh Ahmad Pramudiyanto, Supana \& Muhammad Rohmadi yang berujudul "Karakteristik Wong Cilik Pada Wanda Wayang Kulit Tokoh Panakawan". Pemanfaatan teori semiotik dari Barthes untuk melihat makna dibalik wanda wayang kulit tokoh Panakawan. Tokoh Semar yang menunjukkan nilai dan karakter religius seperti gambaran wong cilik (Pramudiyanto, Rohmadi, \& Supana, 2018)

Pemilihan tema spiritualitas dengan memanfaatkan teori semiotik dari Roland Barthes juga telah dilakukan oleh beberapa peneliti, antara lain penelitian yang dilakukan oleh Aisyah Yusdiani menunjukkan bahwa terdapat tanda-tanda spiritualitas dalam kumpulan cerpen Lelaki Yang Membelah Bulan karya Noviana Kusumawardhani menunjukkan bahwa spiritualitas hadir dalam setiap hal yang dilakukan manusia baik scara sadar ataupun tidak sadar(Yusdhiani, 2014). Joko Susilo dalam penelitiannya menemukan formulasi pesan tentang seksualitas dan spiritualitas yang terdapat dalam Serat Centhini(Susilo, 2018). Pada penelitian ini spiritualitas tidak hanya berfokus pada penemuan makna dalam karya novel Hipernova saja melainkan juga menunjukkan spiritualitas pada karakter tokoh Novae yang sangat berperan kuat dalam membangun makna spiritualitas. Sehingga pemaknaan spiritualitas menjadi lebih luas dan mendalam.

\section{TEORI DAN METODOLOGI}

Penelitian ini memanfaatkan teori dari Roland Barthes sebagai teori utama untuk mengungkap spiritualitas tokoh Novae dalam novel Hipernova karya Fariza Auliya Jasmine. Penelitian ini memanfaatkan analisis naratif struktural Barthes sebab objek penelitian ini adalah teks sastra. Analisis struktur naratif meliputi lima kode semiologi Barthes untuk menunjukkan adanya nilai-nilai spiritual yang melekat pada tokoh sehingga dapat memahami makna spiritualisme pada tokoh Novae dalam novel Hipernova. 
Langkah analisis, Diawali dengan memilih penanda-penanda yang ada pada teks (unit of reading) ke dalam bentuk kutipan yang beruntun (lexias). Penanda pada teks merujuk kode semiotik yang merujuk pada lima kode pokok semiotik Barthes. Barthes menyatakan bahwa adanya tanda (sign) didapat dari sebuah hubungan atau relasi antara relata (tanda). Relasi tersebut merujuk pada tanda yang berhubungan dengan teks ataupun konteks dari teks, seperti representasi tanda. Tanda ada disebabkan oleh kode yang berasal dari konvensi atau sistem kesepakatan sosial (social convention) yang ada. Sehingga, analisis teks dengan kombinasi tanda mampu menghasilkan makna yang berdasar pada tanda yang dari makna hubungan konvensi (Barthes, 1964).

Lebih lanjut, Barthes menyebutkan keterbukaan makna dari tanda terbagi menjadi dua yaitu denotasi dan konotasi. Denotasi merupakan tanda yang mampu menghasilkan makna secara jelas. Sedangkan konotasi merupakan tanda yang menghasilkan makna tersembunyi yang dapat dijelaskan secara konvensional. Posisi mitos berada pada tandatanda yang dibentuk berdasar konotasi. Mitos merupakan bentuk tanda yang dibangun dari berbagai sistem kesepakatan sosial yang ada (Barthes, 1991).

Dalam kajian karya sastra Barthes menggunakan analisis naratif struktural dalam mengungkap makna (structural analysis of narrative) yang juga dikenal sebagai teks dengan fokus kajian pada teks. Barthes juga menambahkan bahwa setidaknya terdapat lima kode pokok yang terdapat pada leksia yang dapat dikelompokkan.

1) Kode Hermenutik (HER) merupakan kode teka-teki yang terstruktur yang ada dalam teks yang dapat diformulasikan sesuai dengan pendapat pembaca. Kode hermenutik merujuk pada harapan pembaca dalam menemukan kebenaran atsa pertanyaan yang ada pada teks. Kode tersebut merupakan unsur utama yang terstruktur dalam narasi teks. Terdapat sebuah kesinambungan dalam teks berupa munculnya suatu peristiwa teka-teki dan penyelesaian dalam cerita.

2) Kode Semes (SEME) merupakan kode konotatif yang menawarkan simbolik. Dalam hal ini kode semes merupakan kode yang memanfaatkan petunjuk atau kilasan makna yang ditimbulkan oleh penanda.

3) Kode Simbolik (SYM) merupakan kode yang memuat tentang serangkaian antitesis. Kode simbolik merupakan aspek pengkodean fiksi yang struktural. Fokus pemhaman kode simbolik berada pada bentuk penggunaan karakter yang ada pada teks. Kode simbolik cenderung muncul berulang dalam sebuah teks sehingga mudah untuk dikenali.

4) Kode Proaretik (ACT) merupakan setiap leksia menunjukkan makna plural berdasar pengalaman pembaca. Kode proaretik memuat adanya unsur cerita atau narasi yang merujuk pada suatu tindakan. Mengimplikasikan suatu logika prilaku manusia berupa tindakan yang memberikan dampak.

5) Kode Kultural (REF) merupakan kode yang mengacu pada benda yang sudah dikonstruksi oleh pengetahuan tanpa merekonstruksi budaya tertentu. Kode kultural merujuk pada suara-suara yang bersifat kolektif, anonym, bawah sadar, mitos, kebijaksanaan, pengetahuan, sejarah, moral, psikologis, sastra, seni, dan legenda. 
Unsur kode yang ada dibentuk oleh beragam pengetahuan dan kebijaksanaan yang bersifat kolektif (Barthes, 2002).

Lima kode semiology dapat menunjukkan tindakan tokoh Novae yang merujuk pada nilai-nilai spiritual. Spiritualitas sendiri bermula dari praksis yang merupakan kegiatan atau cara hidup religius yang kemudian bertransformasi menjadi sebuah kepercayaan atau keyakinan yang berdampak pada prinsip hidup (Conttingham, 2005). Pernyataan ini kemudian didukung oleh Nelson (2009) yang mendefinisikan spiritualitas sebagai kekuatan yang tak dapat diukur dan melebihi batas praksis religius yang sangat berdampak pada kehidupan kita Memiliki jiwa spiritualitas artinya dapat memahami pentingnya kehidupan diluar kebutuhan duniawi yang memicu nafsu dan ego dan menyadari bahwa manusia merupakan bagian penting dari sebuah kehidupan di alam semesta. Berbagai pertanyaan tentang keberadaan Tuhan, makna hidup, keberadaan mutlak hukum moral merupakan contoh polemik dari seseorang yang sedang ada dalam proses pencarian spiritualitas diri (Spencer, 2012). Dengan demikian, nilai-nilai spiritual dapat ditinjau dari tindakan Novae dalam hubungannya dengan Tuhan, menemukan makna atau tujuan hidup, idealisme dalam hidup.

Penjelasan spiritualisme diatas sejalan dengan Elkins (1998) menegenai aspek spiritualitas dalam diri individu diantaranya;

1) Aspek transdental dimana seseorang spiritual meyakini lebih dalam terhadap sesuatu yang dilihat dan dirasakan serta meyakini bahwa keinginan diri sendiri ditentukan oleh hubungan baik dengan aspek transenden.

2) Makna hidup, seorang spisritual akan memiliki makna hidup dan juga tujuan hidup yang diperoleh dari proses pencarian makna hidup secara terus-menerus. Pencarian tersebut akan bertemu pada sebuah titik keyakinan bahwa kehidupan penuh dengan makna.

3) Misi dalam hidup, seorang spiritualis akan memiliki rasa tanggung jawab yang tinggi terhadap keputusan yang dipilihnya.

4) Altruisme, seorang spiritualis akan menyadari bahwa setiap manusia merupakan saudara.

5) Idealisme, seorang spiritualis akan menyadari dan menghormati potensi positif yang ada pada kehidupan individu.

6) Seorang spiritualis memiliki kesadaran untuk memahami makna dari setiap rasa sakit, penderitaan, atau bahkan kematian.

7) Kesucian dalam hidup, seorang spiritualis memahami bahwa kehidupan dan hubungannya dengan transenden harus denagn jiwa yang suci

8) Seorang spiritualis akan menyadari bahwa kebahagiaan tertinggi berasal dari nilainilai spiritual.

9) Manfaat spiritualitas pada seorang spiritualis diwujudkan melalui hubungan baik antar Tuhan, sesama, dan alam.

Makna spiritualitas dan aspek spiritual diatas merupakan pendekatan dalam memahami konsep spiritual yang akan dipakai dalam penelitian ini. Oleh sebab itu, spiritualitas tokoh Novae dalam novel Hipernova dilihat dari adanya tindakan dan nilainilai spiritual pada diri tokoh. 
Dengan demikian, penelitian ini bersifat deskriptif kualitatif dengan memanfaatkan teori dan metode semiotik dari Roland Barthes. Penelitian jenis deskriptif kualitatif merupakan bentuk penelitian yang fokus pada deskripsi makna data yang ditemukan ataupun fenomena yang ditemukan oleh peneliti. Hal ini didukung dengan menujukkan bukti-bukti pendukung data. Kemampuan dan ketajaman seorang peneliti berperan sangat penting dalam menganalisa setiap sisi pemahaman akan fenomena sehingga dapat memberikan makna yang bersifat luas dan menyeluruh namun tetap fokus akan suatu gejala yang telah dideskripsikan (Jabrohim, 2003)

Sumber data penelitian adalah novel Hipernova karya Fariza Auliya Jasmine. Novel Hipernova diterbitkan oleh Tinta Medina, Tiga serangkai pada tahun 2018. Cetakan novel Hipernova terdiri dari 230 halaman. Pengumpulan data penelitian dilakukan dengan studi pustaka. Suhariyadi (2014, hal. 93) menyatakan bahwa pengumpulan data dengan studi pustaka meliputi teknik baca, simak, dan catat untuk kemudian dilanjutkan dengan menganalisis data. Teknik baca, teknik simak, dan teknik catat, tersebut dilakukan dengan menyesuaikan fokus penelitian pada kualitas karya sastra. Teknik baca dilakukan dengan melakukan pembacaan secara berulang dan mendalam terhadap objek kajian. Teknik simak dilakukan dengan memerhatikan tulisan, bahasa, atau narasi yang merujuk pada deskripsi tokoh atas spiritualitas yang dimiliki tokoh utama, Novae. Teknik analisis data dilakukan dengan memanfaatkan teori semiotik dari Roland Barthes yaitu telaah struktur naratif melalui lima kode semiology Barthes. Teknik analisis data meliputi identifikasi struktur naratif teks novel Hipernova melalui lima kode semilogi Barthes. Hal tersebut dapat menunjukkan tindakan Novae yang merujuk apda nilai-nilai spiritual yang ada pada diri tokoh. Selanjutnya, analisis dilanjutkan denagn menjelaskan dan memahamil nilainilai spiritual pada tokoh merujuk pada pemahaman konsep spiritual dari Elkins.

\section{HASIL DAN PEMBAHASAN}

\section{Identifikasi Struktur Naratif Teks Novel Hipernova}

Hasil analisis data didapat dengan menguraikan dan mendeskripsikan objek penelitian demam memanfaatkan teori semiotika Barthes. Langkah awal peneltian dengan mengidentifikasi adanya tanda-tanda yang merujuk pada lima kode semiologi Barthes yang ada dalam teks. Terdapat lima kode yang merujuk pada spiritualitas Novae dalam novel Hipernova, diantaranya;

\section{Kode HER}

Kode HER (Barthes, 1991) merupakan kode yang merujuk pada teka-teki yang terstruktur yang ada dalam teks. Kode tersebut ditemukan berdasarkan pembacaan yang membuat peneliti menyadari bahwa kode tersebut mampu menuntut pada kebenaran atas pertanyaan yang ada pada teks. Kode tersebut merupakan unsur utama yang terstruktur dalam narasi teks.

Seperti yang tertera pada judul novel yaitu "Hipernova". Kata 'hipernova' mengundang berbagai pertanyaan namun menunda jawaban sehingga menimbulkan tekateki. Teka-teki tersebut merujuk pada sebuah pertanyaan tentang apa atau bahkan siapa 
atas makna dibalik kata 'hipernova'. Teka-teki mengarahkan pada analisis selanjutnya untuk mengetahui makna 'hipernova'.

Novel Hipernova memiliki anak judul yaitu, sang paradoks, pesujud, dan monotheisme. Farasa kata 'sang paradoks' merujuk pada suatu keyakinan atau faham seseorang tentang sesuatu yang berlawanan tetapi pada kenyataannya mengandung sebuah kebenaran. Kata 'pesujud' merujuk pada kepatuhan terhadap suatu kepercayaan. Kata 'Monotheisme' merujuk pada suatu kepatuhan terhadap suatu kepercayaan kepada satu Tuhan. Ketiga anak judul tersebut merujuk pada sebuah kekuatan yang ada di dalam diri terhadap suatu kepercayaan. Ketiga anak judul tersebut semakin menambah pertnayaan tentang apa makna atau cerita dibalik judul Hipernova: Sang Paradoks, Pesuud, dan Monotheisme. Dengan demikian penanda dari judul ini dapat digambarkan sebagai kode semiotik (HER: teka-teki, cerita dibalik kata hipernova?).

\section{Kode SEM}

Kode semes (Barthes, 1991) merupakan kode konotatif yang menawarkan simbolik. Dengan demikian, pemilihan kode sem memanfaatkan petunjuk yang dituimbulkan oleh penanda. Kode HER menunjukkan bahwa kata 'hipernova' meruapkan teka-teki yang mengarah pada analisa selanjutnya. Kata 'Hipernova' sendiri menimbulkan makna konotasi yang merupakan ledakan cahaya bintang yang sangat cemerlang. Unit kata cahaya, cemerlang merujuk pada unsur-unsur serupa yang mencipatakan suatu karakter. Unit ini kemudian menjadi penanda khusus karena cahaya mempunyai arti jernih, putih. Hal ini menjadi petunjuk pada penanda selanjutnya. (SEM: cahaya, putih)

Petunjuk pada penanda tersebut merujuk pada karakter tokoh utama, Novae yang digambarkan sebagai seorang model penderita albino yang telah lama berhenti mempercayai Tuhan. Deskripsi tokoh Novae dibentuk menjadi sosok yang putih bersih dari badannya yang putih, warna rambut dan bulu matanya. Seperti pada kutipan berikut;

Orang-orang dilantai itu memperhatikannya. Memperhatikan dari ujung rambut hingga ujung kakinya yang berwarna putih---kecuali busananya. Benar, sekujur tubuhnya putih, ini bukan metafora atau syair klasik tak bertuan. Selain kulitnya yang putih membeku, tatanan kedua alisnya, bulu mata, bahkan bibir kecil namun tebal dibagian bawah yang menyerupai bentuk hati pun berwarna putih, terlebih tak ada riasan sama sekali di wajah itu. (Jasmine, 2008, hal. 2)

“...kakinya yang jenjang dan putih terurai lurus ke depan. Kemudian tubuhnya sedikit dibungkukkan, membuat rambut putihnya menutupi setengah wajah....Alis dan bulu mata lebat yang berwarna putih itu sengaja dibiarkan apa adanya. (Jasmine, 2018, p.4)

Penggambaran tokoh Novae yang putih bersih. Hal ini dapat dilihat dari tandatanda yang ada pada kutipan bahwa Novae memiliki warna kulit yang putih hingga rambutnya yang kemudian menghasilkan makna bahwa Novae merupakan sosok yang bersih. Berdasarkan penelitian yang dilakukan oleh Zuhriah (2018) dengan kajian semiotik menyebutkan bahwa warna putih merujuk pada makna kemurnian dan cahaya, kebebasan dari keganasan atau niat jahat. Seperti pada pengantin wanita yang cenderung memakai baju putih yang melambangkan kesucian dan kemurnian. Sampai pada titik ini, teks masih menimbulkan teka-teki mengenai ateisme pada tokoh Novae namun 
digambarkan sebagai seorang yang putih bersih yang merujuk pada makna kesucian atau kemurnian.

\section{Kode SYM}

Kode Simbolik merupakan kode yang merujuk pada serangkaian antitesis. Serangkaian antitesis yang ada pada teks novel Hipernova berasal dari pembahasan yang bertolak belakang antara kedua tokoh, yaitu tokoh Novae dan Hipernova. Tokoh Hipernova merupakan penulis scrapbook yang dibaca oleh Novae. Scrapbook merupakan ringakasan kehidupan tokoh utama, Novae selama lima tahun terahir. Tulisan scrapbook memuat berbagai jawaban atas pertanyaan Novae selama ia berhenti memercayai Tuhan. Tulisan scrapbook yang tidak hanya memuat argumen kosong namun pendapatnya juga dibuktikan dengan kutipan dari Al-Quran, hadist, dan lainnya. Hal tersebut menunjukkan bahwa tokoh Hipernova merupakan seorang yang religius dengan pemahaman agama yang kuat. Keadaan tersebut membuat teks novel Hieprnova memuat adanya serangkian antitesis yang tampak dari perbedaan pemahaman keyakinan antara Novae dan Hipernova. Beberapa diantaranya;

\section{1) Kode SYM beragama (keyakinan diri vs warisan)}

Pada antitesis sebelumnya menunjukkan bahwa Novae mrupakan yang ateis yang juga berdampak pada ketidakpercayaannya terhadap agama. Kuitpan berikut menunjukkan bagaimana realitas gambaran sebagian pemahaman seseorang akan memeluk agama. Latar tempat berada disebuah lokasi vihara bernama Brahma Arama di desa Banjar Tegeha, Bali. Diceritakan bahwa kehidupan penduduk daerah tersebut menunjukkan adanya toleransi beragama yang kuat. Bagaimana agama Islam dan Hindu mampu hidup berdampingan tanpa terusik satu dengan yang lain. Hal tersebut kemudian membuat Novae berpikir bahwa sebagian besar orang beragama hanya mengikuti apa yang dianut keluarga. Seperti pada kutipan;

"Disini seluruh penduduknya sangat bertoleransi, walau hanya berdampingan antara kaum muslim dan kaum Hindu. Kaum Hindu nggak terusik sama sekali dengan suara keras adzan dari masjid lima kali dalam sehari, begitu pun kaum muslim yang ngak akan mengganggu saat penduduk sedang merayakan Nyepi" tambah Kim. Akhirnya, kau mulai memasang tampang berpikir khasmu

... "Mereka yang beragama hanya mengikuti apa yang dianut keluarganya, tanpa berpikir apakah mereka menganut sesuatu yang benar atau tidak. Mereka hidup berdampingan, tetapi apakah mereka nggak berpikir sedikit saja, manakah dari ajaran keduanya yang benar dan manakah yang keliru?"..

"... sebenarnya mereka pun nggak benar-benar mendalami ilmu agama masing-masing sehingga muncullah julukan 'agama KTP'.....

"Tetapi nggak semua orang seperti itu. Sudah banyak orang-orang berpikir di era ini" ... "mereka mulai menyandingkan ajaran agama mereka dengan agama lain. Mereka mempelajari agama satu ke agama lainnya. Mencari kebenaran atas satu ajaran agamayang hakiki, bukan mencari pembenaran. Mengedepankan logika dan bukan sekadar perasaan."(Jasmine, 2008, hal. 49-50)

Kutipan tersebut menunjukkan adanya toleransi beragama yang terjadi di Bali. Novae memandang bahwa sebagian besar orang beragama hanya menerima apa yang 
menjadi kepercayaan keluarganya. Namun, mereka tidak mau berpikir lebih dalam mengenai agama yang diterimanya sebagai warisan. Keadaan tersebut menjadi kegundahan Novae atas buruknya realitas dalam memeluk agama. Keadaan atau gambaran realitas tersebut lebih dikenal dengan agama KTP dimana seseorang memeluk agama hanya sebuah formalitas yang mengharuskan individu untuk memeluk agama. Pandangan tersebut kemudian dibantah oleh Hipernova yang menyatakan bahwa tidak semua orang menjadikan agama sebagai warisan dan menunjukkan bahwa agama merupakan bentuk kebenaran yang hakiki. Individu yang memeluk agama atas pencarian diri dan keyakinan diri akan menemukan kedaiaman dalam dirinya. Sanggahan Hipernova tersebut menimbulkan adanya hubungan antitesis mengenai memeluk agama berdasarkan warisan vs agama sebagai pilihan nurani.

\section{2) Kode SYM (ateis vs monoteis)}

Scrapbook merupakan media Hipernova untuk mememengaruhi keyakinan Novae terhadap Tuhan. Tokoh Hipernova yang religius berpadu dengan keyakiann Novae yang ateis. Keadaan tersebut merujuk pada hubungan antitesis ateis vs monoteis. Kutipan berikut menunjukkan bahwa Novae merupakan seorang ateis;

"aku nggak pernah menyembah-Nya, nggak pernah mengakui keesaan-Nya, nggak pernah meminta pertolongan-Nya sedikit pun, bahkan aku sering mencaci-Nya. Tetapi, sampai detik ini semua yang aku inginkan dalam hidup bisa kudapati, tidak berkurang satu pun" (Jasmine, 2008, hal. 71-72)

... Mungkin, tampak masuk logika ketika kamu tidak memercayai Tuhan, tetapi pertolongan selalu datang, lantas untuk apa lagi memercayai Tuhan? Ketahuilah bahwa semua yang terjadi saat ini adalah murni refleksi atas salah satu nama Tuhan dari 99 yang Dia miliki, yaitu Ar-Rahman. (Jasmine, 2008, hal. 77)

Kutipan pertama merupakan pernyataan Novae bahwa ia seorang ateis. Keyakinannya tersebut dinyatakan secara tegas bahwa ia tidak pernah mengakui keesaanNya dan tidak pernah meminta pertolongaan pada Tuhan. setiap keinginan Novae selalu terpenuhi tanpa harus mengimani Tuhan. Hal tersebut dibantah oleh Hipernova dan menekankan bahwa Tuhan itu ada dan kehidupan di dunia merupakan bentuk hubungan sebab akibat. Ada tidaknya manusia yang menyembah Tuhan tidak menjadikan Tuhan murka namun semuanya merupakan kehendaknya dalam mengasihi manusia diama Tuhan merupakan maha pengasih. Kedua kutipan tersebut menimbulkan adanya antitesis antara ateis dan monoteis.

\section{3) Kode SYM (Berharap vs tidak berharap)}

Pernyataan ini merujuk pada antitesis dimana terdapat sebuah tanda yang menunjukkan pertentangan atau perlawanan. Seperti yang ada pada kutipan berikut;

“...tidak pernah berharap, dalam kondisi apa pun, saya tidak pernah menaruh harap denggan seorang pun. Seorang pun." (Jasmine, 2018, p.60)

“...hal ini lah yang membuatmu dapat dikatakan jauh lebih beriman daripada para manusia yang mengimani Tuhan, tetapi menaruh harap pada manusia. Kamu menyatakan tidak mengimani Tuhan, tanpa pernah kamu tahu bahwa kamu jauh lebih beriman daripada manusia bertuhan, tetapi menuhankan manusia"(Jasmine, 2018, p.65). 
Pada kutipan pertama dapat disimpulkan bahwa Novae digambarkan sebagai seseorang yang tidak pernah berharap pada manusia. Hal ini menjadi pernyataan pertama yang kemudian bertentangan dengan pernyataan kedua dimana masih banyak manusia yang mengaku bertuhan namun menaruh harap pada manusia (SYM: berharap, tidak berharap). Sedangkan pada kutipan kedua menyatakan bahwa Novae adalah manusia beriman melebihi manusia yang bertuhan. Tanda-tanda yang muncul pada kutipan tersebut memuat penanda tersebut menyimpulkan makna bahwa Novae merupakan orang yang beriman.

\section{Kode REF}

Kode Kultural (REF) merupakan kode yang mengacu pada benda yang sudah di konstruksi oleh pengetahuan tanpa merekonstruksi budaya tertentu (Barthes, 2002). Novel Hipernova memuat banyak ilmu pengetahuan dalam membangun teks novel, utamanya pengetahuan tentang agama Islam. Adanya kutipan Al-Quran, hadis, dan beberapa literatur lainnya pendukung tema religi novel Hipernova. Hal tersebut memperkaya pengetahuan pembaca dalam membaca novel Hipernova.

Ketahuilah bahwa semua yang terjadi saat ini adalah murni refleksi atas salah satu nama Tuhan dari 99 yang Dia miliki, yaitu Ar-Rahman. (Jasmine, 2008, hal. 77)

“... Teori yang sebenarnya telah ditemukan sejak 14 abad lalu, saat seorang manusia paling mulia shallahu 'alaihi wasallam memerintahkan untuk selalu berpuasa tiga hari di setiap tengah bulannya. Puasa ayyamul bidh, namanya. Puasa yang dilakukan setiap tanggal 13, 14, 15 penanggalan komariah."

“... Dan nggak kalah penting, di suatu surah dalam Al-Quran pun telah dijelaskan, yaitu pada surah Al-Falaq ayat 1 sampai 3."

"Qul a'uudzu birabbil falaq, min syarri mas khalaq, wa min syarri ghaasiqin idzaa waqab. 'katakanlah, aku berlindung kepada Tuhan yang menguasai Shubuh, dari kejahatan (makhluk yang) Dia ciptakan, dan dari kejahatan malam apabila telah gelap gulita'. (Jasmine, 2008, hal. 110-111)"

Kutipan tersebut merupakan salah satu kutipan yang menunjukkan adanya pengetahuan tentang ilmu agama Islam. Kutipan pertama menunjukkan bahwa teks novel Hipernova merujuk pada pengetahuan tentang 99 nama-nama Allah SWT (Asmaul Husna) yaitu Ar-Rahman yang artinya Allah SWT Maha Pengasih. Hal tersebut menunjukkan penanda yang merujuk pada kode kultural (REF: pengetahuan Asmaul Husna)

Kutipan kedua merupakan salah satu hadis Rasulullah yang memerintahkan untuk berpuasa sunah ayyamul bidh pada tanggal 13,14, 15. Kutipan selanjutnya merupakan kutipan dari surah Al-Falaq untuk menegaskan sunah nabi mengenai perintah puasa sunah. Adanya hadis Rasulullah dan kutipan Al-Quran dalam teks novel memberikan ilmu pengetahuan tentang berpuasa sunah. Hal tersebut menjadi penanda yang merujuk pada kode kultural berupa (REF: ajaran puasa sunnah).

\section{Kode ACT}

Kode proaretik (ACT) merupakan kode yang memuat satu narasi cerita yang merujuk pada satu tindakan. Salah satu kutipan berikut merupakan narasi cerita yang 
merujuk pada tindan Novae yang memberikan dampak besar pada kehidupannya dalam menemukan dan menguatkan jiwa spiritualisme dalam dirinya.

"saat ini kamu bukanlah seseorang yang tidak melakukan apa pun karena kamu bekerja. Artinya, kamu telah melakukan yang namanya ibadah. Meski kamu tidak mempercayai sang Pemberi karunia itu sendiri, itu tak mengapa. Sebab, kamu lebih baik dari orang-orang yang mengimani keesaan Tuhan, tetapi mereka bergantung pada orang lain, meminta-minta, tidak menggunakan tangan dan kaki mereka untuk bekerja, seolah tidak pernah tahu bahwa Tuhan telah menjamin rejeki setiap mahluknya...bukankah kamu jauh lebih mengimani eksistensi Tuhan dibanding mereka yang bertuhan?" (Jasmine, 2008, p. 145)

Beberapa tanda yang ada pada kutipan di atas antara lain; bekerja, ibadah, mengimani, bertuhan. Tanda tersebut berkaitan satu dengan yang lainnya membentuk sebuah makna yang menyimpulkan bahwa Novae merupakan sosok yang beriman dan mengimani eksistensi Tuhan dibandingkan dengan fakta manusia-manusia yang mengaku bertuhan. Tanda-tanda tersebut menunjukkan tindakan dari tokoh (ACT: bekerja, ibadah) yang menunjukkan keimanan Novae dalam meyakini eksistensi Tuhan. Dalam hal ini, tokoh Hipernova mencoba mengubah sudut pandang Novae yang ateis dengan mencoba meyakinkan Novae bahwa ia merupakan sosok yang beriman dan memiliki jiwa yang spiritualis. Pada kutipan tersebut, penanda juga merujuk pada kode kultural yaitu (REF:Agama $\rightarrow$ ibadah, mengimani, bertuhan) merupakan tanda yang mengacu pada kepercayaan terhadap Tuhan terhadap agama tertentu.

Pada kode proaretik (ACT) merujuk pada tindakan Novae 'bekerja' yang diasumsikan sebagai bentuk tindakan yang mengacu pada kemampuan Novae dalam bersyukur atas kemampuan fisiknya sehingga tindakan bekerja dilakukan tanpa harus menaruh harap lebih kepada sesama manusia. Dalam hal ini, Novae bekerja hanya untuk memenuhi kebutuhannya dan tidak mengharap lebih dari sekadar bekerja. Tindakan tersebut menunjukkan sikap Novae yang lebih baik dibandingkan dengan mereka yang mengaku berTuhan.

Pembacaan scrapbook membantu Noave dalam memahami makna hidupnya lebih dalam. Ahir cerita novel Hipernova menunjukkan bahwa Novae mengucapkan dua kalimat syahadat yang menunjukkan bahwa ia telah beriman kepada Allah SWT.

“... Detik kelima, dia membuka mata, lalu menganjur napas panjang. 'saya ... bersaksi... bahwa,' rebas, air matanya menjadi-jadi. Orang-orang menyorotnya penuh. Speaker yang menggema sesisi pameran membuat orang-orang mematung.

"Bahwa tidak ada Tuhan selan Allah, dan saya bersaksi Nabi Muhammad Shallallahu alaihi wasallam ... adalah utusan-Nya ... 'Asyhadu alla ilaha illallah.. wa asyhadu anna muhammadar rasulullah' (Jasmine, 2008, p. 222)

Kutipan tersebut menunjukkan bahwa Novae telah melafalkan dua kalimat syahadat (ACT: melafalkan) dengan penuh haru di hadapan publik. Pada kutipan tersebut menunjukkan bahwa setiap orang yang datang menyaksikan momen sakral tersebut. Kutipan tersebut merupakan bacaan syahadat yang menunjukkan bahwa Novae telah meyakini eksistensi Allah SWT. Syahadat meruapkan bentuk pernyataan dan sekaligus 
pengakuan akan keesaan Allah SWT dan Nabi Muhammad sebagai Rasulnya. Novae menyadari bahwa keprcayaannya kepada Allah SWT harus dilakukan dengan pernuh rasa tanggung jawab dan melaksanakan setiap tindakan harus merujuk pada Allah SWT dan hadist. Novae kemudian menunjukkan komitmen keyakinnanya terhadap agama yang dianutnya. Hal tersebut ditunjukkan dengan narasi cerita yang merujuk pada kode proaretik (ACT) berupa (ACT: bersedekah)

"Kamu nggak perlu menghawatirkan soal pekerjaan, 35 persen hartaku sudah kuhibahkan untukmu. Kamu bisa menjalankan binis atau mungkin melanjutkan kuliah"

"5\% harta kuberikan pada Gigi termasuk sebuah mobil. 35\% harta telah menjadi milikmu, berikut aset seperti apartemen dan mobil. 50\% harta akan kusumbangkan kepada yayasan yang Hipernova bangun" (Jasmine, 2018, 227)

Pada kutipan tersebut menunjukkan bahwa Novae telah membagikan sebagian hartanya denagn rincian 35\% kepada Kim, 5\% kepada Gigi salah satu driver Novae, dan $50 \%$ hartanya ia berikan kepada yayasan yang dibangun oleh Hipernova. Hal tersebut menunjukkan tindakan bersedekah (ACT: bersedekah) kepada orang yang membutuhkan. Bersedekah merupakan bentuk tanggung jawab terhadap keputusan yang dipilih dan suatu bentuk kepatuhan Novae terhadap perintah Allah SWT.

Dengan demikian, judul Hipernova (HER: teka-teki, cerita dibalik kata hipernova?) merujuk pada sebuah tokoh Hipernova yang merupakan penulis scrapbook. Hipernova menjelaskan secara detail kehidupan Novae selama lima tahun terahir dan memberikan gagasan luas atau ilmu pengetahuan (REF: pengetahuan Islam berupa kutipan Al-Quran, Hadis, kutpan salah satu asmaul husna) tentang agama Islam kepada Novae melalui scrapbook. Scrapbook mampu menjadi media Novae untuk memahami makna kehidupan dengan berbagai paradoks kehidupan yang melatarbelakangi ditulisnya scrapbook. Paradoks kehidupan ditunjukkan oleh hubungan antitesis yang terbentuk pada kode simbolik (SYM: beragama berdasarkan keyakinan diri vs warisan), (ateis vs monoteis),(Berharap vs tidak berharap). Pengetahuan pada scrapbook mampu mengantarkan Novae pada sebuah titik untuk ahirnya percaya kepada Allah SWT. Novae kemudian mengucapkan dua kalimat syahadat (ACT: mengucap dua kalimat syahadat) dan mampu bertanggung jawab kepada keputusan yang dipilihnya. Novae kemudian menunjukkan tindakan dengan bersedekah (ACT: tindakan sedekah) kepada orang yang membutuhkan. Hal tersebut dilakukan sebagai bentuk kepatuhan Novae kepada Allah SWT.

Berikut tabel yang menunjukkan hasil identifikasi struktur naratif teks novel Hipernova dengan memanfaatkan teori semiologi Barthes;

Identifikasi struktur naratif semiologi Barthes

\begin{tabular}{|l|l|l|l|}
\hline No & \multicolumn{1}{|c|}{ Nama Kode } & \multicolumn{1}{c|}{ Kode pada Teks } & \multicolumn{1}{|c|}{ Penjelasan Kode Semiologi } \\
\hline 1 & $\begin{array}{l}\text { Kode Hermeneutik } \\
\text { (HER) }\end{array}$ & $\begin{array}{l}\text { (HER: teka-teki, cerita dibalik } \\
\text { kata hipernova?) }\end{array}$ & $\begin{array}{l}\text { merujuk pada sebuah } \\
\text { pertanyaan tentang apa atau } \\
\text { bahkan siapa atas makna } \\
\text { dibalik kata 'hipernova' }\end{array}$ \\
\hline 2 & Kode Semes (SEM) & (SEM: cahaya, putih) & $\begin{array}{l}\text { merujuk pada karakter tokoh } \\
\text { utama, Novae yang } \\
\text { digambarkan } \\
\text { menjadi sosok yang putih }\end{array}$ \\
\hline
\end{tabular}




\begin{tabular}{|c|c|c|c|}
\hline & & & $\begin{array}{l}\text { bersih dari badannya yang } \\
\text { putih, warna rambut dan bulu } \\
\text { matanya. }\end{array}$ \\
\hline \multirow[t]{3}{*}{3} & \multirow[t]{3}{*}{ Kode Simbolik (SYM) } & $\begin{array}{l}\text { 1) Kode SYM beragama } \\
\text { (keyakinan diri vs warisan) }\end{array}$ & $\begin{array}{l}\text { 1) Pandangan Hipernova } \\
\text { bahwa sebagian besar orang } \\
\text { yang beragama sesuai } \\
\text { dengan keyakinan hati dan } \\
\text { realitas dari Novae yang } \\
\text { memandang seseorang } \\
\text { memeluk agama karena } \\
\text { agama merupakan warisan } \\
\text { sehingga sebagian orang } \\
\text { beragama KTP }\end{array}$ \\
\hline & & $\begin{array}{l}\text { 2) Kode SYM (ateis vs } \\
\text { monoteis) }\end{array}$ & $\begin{array}{l}\text { 2) perdebatan tentang } \\
\text { pandangan mengenai } \\
\text { keyakinan Novae yang ateis } \\
\text { dan Hipernova yang } \\
\text { monoteis }\end{array}$ \\
\hline & & $\begin{array}{l}\text { 3) Kode SYM (Berharap vs tidak } \\
\text { berharap) }\end{array}$ & $\begin{array}{l}\text { 3) Keadaan Novae yang tidak } \\
\text { pernah berharap pada } \\
\text { siapapun beradu dengan } \\
\text { realitas yang menunjukkan } \\
\text { bahwa sebagian besar orang } \\
\text { berharap dan bahkan } \\
\text { menuhankan manusia }\end{array}$ \\
\hline 4 & Kode Kultural (REF) & $\begin{array}{l}\text { (REF: pengetahuan Asmaul } \\
\text { Husna) } \\
\text { (REF: ajaran puasa sunnah). }\end{array}$ & $\begin{array}{l}\text { Adanya narasi teks yang } \\
\text { merujuk pada satu ilmu } \\
\text { pengetahuan tentang agama } \\
\text { Islam yang ditunjukkan } \\
\text { dengan Adanya kutipan AL- } \\
\text { Quran, Hadis, pengetahuan } \\
\text { tentang } 99 \text { nama-nama Allah } \\
\text { SWT. }\end{array}$ \\
\hline 5 & $\begin{array}{l}\text { Kode Proaretik } \\
\text { (ACT) }\end{array}$ & $\begin{array}{l}\text { (ACT:Bekerja) } \\
\text { (ACT: melafalakan dua kalimat } \\
\text { syahadat) } \\
\text { (ACT: bersedekah) }\end{array}$ & $\begin{array}{l}\text { Tindakan bekerja tanpa } \\
\text { menaruh harap kepada } \\
\text { manusia secara berlebih atau } \\
\text { menuhankan manusia } \\
\text { Pengakuan ikrar kepada Allah } \\
\text { SWT dan diri serta dibuktikan } \\
\text { dengan melakukan tindakan } \\
\text { membagikan sebagian harta } \\
\text { (sedekah) kepada yang } \\
\text { membutuhkan }\end{array}$ \\
\hline
\end{tabular}

Tabel tersebut merupakan ringkasan sub judul identifikasi struktur naratif semiologi Barthes yang kesemuanya merujuk pada spiritualisme tokoh Novae dalam novel Hipernova karya Fariza Auliya Jasmine. Terdapat lima kode semiologi pada teks novel Hipernova yaitu, Kode Hermeneutik (HER), kode Semes (SEM), kode Simbolik (SYM), kode kultural (REF), dan kode proaretik (ACT).

\section{Spiritualisme Novae dalam Novel Hipernova}

Identifikasi struktur naratif dengan memanfaatkan lima kode semiologi Barthes menunjukkan beberapa nilai atau aspek spiritual yang ada pada tokoh Novae selama ateis 
hingga ia memeluk agama Islam. Aspek spiritual merujuk pada konsep Elkins, diantaranya;

\section{1) Hubungan Novae dengan Allah SWT}

Tindakan Novae untuk melafalkan dua kalimat syahadat (ACT: melafalkan) merupakan awal pengakuannya terhadap keberadaan dan keesaan Allah SWT. Tindakan tersebut menjadi penanda bahwa Novae merupakan seorang Muslim. Tindakan tersebut merupakan hasil dari pemikiran kritis terhadap kehidupan melalui pembacaan scrapbook. Berbagai paradoks kehidupan dipaparkan secara jelas untuk memengaruhi pandangan Novae agar dapat menyadari eksistensi Allah SWT. Pembacaan scrapbook secara intensif dan kemampuan berpikrit kritis mampu menyadarkan Novae akan makna kehidupan dan eksistensi Allah SWT.

Keberhasilan Novae dalam menemukan esensi kehidupan tidak dapat dilepaskan dari kemampuannya atau keterampilan berpikirnya. Hal tersebut dapat dilihat dari caar berpikir Novae dalam memandang fenomena sekitar dan memecahkan pergulaan batin selama pembacaan scrapbook. Berpikir kritis merupakan kemampuan yang sangat esensial untuk kehidupan. Hal tersebut sangat efektif dalam semua aspek untuk menunjang sebuah tatanan kehidupan. Berpikir kritis (Matindas, 1996) menegaskan bahwa berpikir kritis adalah aktivitas mental yang dilakukan untuk mengevaluasi kebenaran akan sebuah pernyataan. Hal tersebut mengantarkan pada sebuah keputusan untuk menerima, menyangkal, atau bahkan meragukan sebuah kebenaran atas pernyataan tersebut. Pembacaan scrapbook yang menceritakan diri Novae mengantarkan pada sebuah pergulatan batin yang mendalam. Beberapa paradoks yang muncul antara realitas kehidupan dan pandangannya di paparkan dengan jelas. Hal tersebut membuat Novae mengevaluasi akan kebenaran yang ada pada scrapbook, menyangkal sebagian pandangan Hipernova, dan bahkan meragukan kebenaran tersebut. Namun, pembacaan yang intensif semakin membuatnya menyadari akan keterbatasan diri dan meyakini keberadaan Allah SWT.

"Lagi-lagi haluan napasnya kacau. Yang dia baca barusan menembus logikanya." (Jasmine, 2008, p. 54)

Kutipan tersebut merupakan salah satu contoh tindakan Novae untuk menyelami pernyataan kebenaran yang ditulis Hipernova pada scrapbook. Beberapa pernyataan Hipernova mampu menembus logikanya sehingga membuatnya untuk berpikir lebih kritis akan kehidupan. Kemampuannya untuk berpikir kritis berujung pada sebuah penerimaan akan kebenaran bahwa ada eksistensi transenden dibalik kehidupan ini. Hal tersebut membuat Novae melihat lebih dalam tentang kehidupan. Novae mampu memahami makna tersembunyi dibalik setiap pernyataan dan refleksi kehidupan Novae dari kacamata Hipernova.

Keadaan tersebut mampu mengantarkannya untuk meyakini kebaradaan Allah SWT dan melafalkan dua kalimat syahadat. Hal tersebut menjadi inti yang mendasar denagn kepercayaan akan adanya sesuatu yang lebih besar dari diri seorang individu. Ada hal yang lebih daripada apa yang terlihat secara kasat mata dan menyadari bahwa yang tidak terlihat dalam hal ini adalah kepercayaan, dapat bermanfaat bagi diri Novae. 


\section{2) Idealisme pada diri Novae}

Sebagaimana pada penejelasan sebelumnya, pembacaan scrapbook yang memuat berbagai ilmu pengetahuan Islam (REF: kutipan Al-Quran, hadist, serta kutipan asmaul husna) mampu menyadarkan Novae akan eksistensi Allah SWT. Pembacaan scrapbook secara intensif membuat Novae memahami dirinya dari sudut pandang Hipernova. Refleksi atas pengalaman hidup Novae selama lima tahun terahir, adanya pengetahuan ilmu agama, idologi serta gamabaran kebudayaan yang ada di Indonesia mampu menumbuhkan idealisme pada diri Novae. Idealisme adalah suatu keyakinan atas suatu hal yang dianggap benar oleh Novae denagn bersumber pada scrapbook dan pencarian atas kebenaran pernyataan scrapbook tersebut.

Idealis meruapkan suatu bentuk pola pikir sesorang untuk bertindak berdasarkan dengan pemikirannya. Pemikiran tersebut dianggap paling benar dan tumbuh dari kesadaran pemikiran (otak). Idealisme inidividu tumbuh secara perlahan dalam diri individu dan ditunjukkan dalam bentuk ide, sikap, atau bahkan cara berpikirnya. Dalam hal ini, idealisme Novae sudah terlihat sejak ia menjadi ateis. Pada saat menjadi ateis, pandangannya akan kehidupan untuk tidak berharap terhadap siapapun dan termasuk Tuhan tidak memengaruhi kehidupannya.

“aku nggak pernah menyembah-Nya, nggak pernah mengakui keesaan-Nya, nggak pernah meminta pertolongan-Nya sedikitpun, bahkan aku sering mencaci-Nya. Tetapi, sampai detik ini semua yang aku inginkan dalam hidup bisa kudapati, tidak berkurang satu pun" (Jasmine, 2008, hal. 71-72)

Kutipan tersebut merupakan pernyataan tegas Novae saat masih belum memepercayai keberadaan Tuhan. Pernyataan tersebut menunjukkan sikap Novae yang sering mencaci Tuhan, tidak pernah meminta pertolongan Tuhan, namun hal tersebut tidak memengaruhi kehidupannya. Kehidupan Novae tetap tercukupi meskipun ia tidak percaya akan keberadaan Tuhan. Pola pikir tersebut merupakan bentuk idealisme kehiudpan Novae selama menjadi ateis. Pola pikir tersebut membuatnya menutup diri terhadap siapapun sehingga tidak menaruh harap pada manusia. Hal tersebut menjadikan sebuah keuntungan ketika sebagian besar orang terlalu menaruh harapan besar pada manusia. Denagn kata lain, sebagian besar orang yang menyatakan dirinya beriman justru menuhankan manusia dan berujung pada sebuah kekecewaan terhadap kegagalan manusia yang diharapkan. (SYM: berharap vs tidak berharap).

Pembacaan scrapbook mampu mengubah pola pikirnya tersebut. Novae mempu memahami secara mendalam tentang dirinya sendiri, pengetahuan agama, dan perbedaan perspektif pandangan akan esensi kehidupan. Novae semakin menyadari akan keterbatasan dirinya dan memahami bahwa Allah SWT merupakan pemegang kebenaran absolut. Hal tersebut mengarahkan Novae untuk bertindak sesuai denagn ajaran yang dianggapnya paling benar sebagaimana yang telah disebutkan pada penjelasan kode semiologi proaretik. Pada penjelasan kode proaretik menyebutkan bahwa Novae membagikan sebagian besar hartanya kepada orang-orang yang membutuhkan. Hal tersebut merupakan bentuk kepatuhan Novae kepada Allah SWT sebagai seorang muslimah yang beriman. 
Berdasarkan pada pembahasan diatas idealisme Novae merupakan bukti yang dapat mematahkan pandangan orang tentang spiritualitas ateisme. Hal ini membantah anggapan yang beredar bahwa orang yang telah lama berhenti mempercayai Tuhan bukan berarti dia tidak memiliki nilai religius dalam hidupnya. Kesadarannya untuk mengikrarkan kembali syahadat dan memilih untuk hanya fokus pada iman terhadap Tuhannya dapat dimaknai bahwa Novae telah menemukan tingkat spiritualitasnya. Spiritualitas Novae juga didukung oleh bukti bahwa Novae telah mempercayai eksistensi Tuhan, mengimani keberadaan-Nya dan tetap menjalankan berbagai kegiatan religius seperti yang telah disebutkan.

\section{3) Makna dan Tujuan Hidup}

Spritualis, orang yang memiliki spiritualitas, merupakan orang yang melakukan kegiatan atau menjalani kehidupan dengan berdasar pada iman atas agama yang diyakini. Seseorang dapat berdoa, melakukan kegiatan ibadah seperti shalat, semedi atau sembahyang, atau membuat keputusan secara sadar, seperti yang telah dilakukan Novae dalam mengikrarkan kembali syahadat, merupakan bentuk nyata dari seseorang dalam menyadari pentingnya dia dalam kehidupan ini (Newman, 2004). Dengan demikian, tokoh Novae dalam novel Hipernova telah melakukan berbagai praksis religius yang bermuara pada inti sebuah kehidupan yaitu spiritualitas.

Hal tersebut didasari dengan adanya pemahaman akan makna hidup sehingga mampu mengantarkannya pada sebuah titik kepercayaan akan keberadaan Allah SWT. Dengan kata lain, Novae mampu memahami proses pencarian kebenaran atau pergulatan batin atas pembacaan scrapbook dalam memperoleh makna hidup dan proses pencarian hidup. Berdasarkan pencarian tersebut, Novae mampu mengembangkan pandangannya bahwa kehidupan memiliki makna. Hal tersebut merujuk pada seuatu pemahaman akan eksistensinya sebagai manusia juga memiliki tujuan. Sebagaimana disebutkan oleh Hipernova yang megutip dari salah satu ayat dalam Al-Quran bahwa tujuan manusia berada di dunia adalah untu beribadah kepada Allah SWT.

"Tidaklah Tuhan mencipatakan Jin dan manusia ke dunia ini, kecuali untuk beribadah kepada-Nya, Ya, beribadah. Jawaban sederhana yang dikutip dari salah satu ayat di dalam Al-Quran. (Jasmine, 2008, p. 143)

Kutipan tersebut mampu menyadarkan Novae akan tujuan hidup manusia di dunia. Sesaat setelah melafalkan dua kalimat syahadat Novae kemudian membagikan sebagian besar hartanya dan menegaskan bahwa tujuan hidupanya setelah itu adalah untuk fokus terhadap hubungan transendenya. Dengan kata lain, Novae memilih untuk beribadah kepada Allah SWT sebagaimana tujuan keberadaan manusia.

"Setelah kamu berhenti dari dunia modelling ... kamu hanya akan mencari Tuhan?"

"Ya" (Jasmine, 2008, p. 226)

Kutipan tersebut merupakan pernyataan tegas Novae akan tujuan hidupnya. Saat ini, Novae menyerahkan kehidupannya sepenuhnya kepada Allah SWT sebagai pemegang kebenaran absolut. Hal tersebut merupakan bentuk kesadaran diri Novae bahwa dia akan terhindar dari segala keputusasaan karena ia telah sepenuhnya percaya terhadap Allah SWT. Komitmen dirinya yang ditunjukkan dengan melafalkan dua kalimat syahadat 
merupakan awal komitemen dalam menentukan langkah kehidupan berikutnya, atau disebut pula misi hidupnya.

\section{SIMPULAN}

Berdasarkan hasil dan pembahasan diatas dapat mengungkap lima kode semiologi Barthes pada teks novel Hipernova yang merujuk pada spiritualitas tokoh Novae dalam novel Hipernova karya Fariza Aulya Jasmine. Kode hermenutik (HER) merujuk pada judul teks penelitian yaitu Hipernova (HER: teka-teki, cerita dibalik kata hipernova?). Kode hermenutik tersebut merujuk pada tokoh yang ada pada teks novel Hipernova yaitu tokoh utama Novae dan tokoh Hipernova yang merupakan penulis scrapbook. Hasil penelitian menunjukkan bahwa Novae memiliki jiwa spiritualitas sehingga ia menjadi penanda representatif atas tokoh dengan fisik yang putih bersih dan ditunjukkan pula pada ahir cerita Novae mengucapkan dua kalimat syahadat. Hal tersebut menunjukkan bahwa Novae merupakan sosok yang kembali suci dan bersih (SEM: putih, bersih).

Hipernova menjelaskan secara detail kehidupan Novae selama lima tahun terahir dan memberikan gagasan luas atau ilmu pengetahuan (REF: pengetahuan Islam berupa kutipan Al-Quran, Hadis, kutpan salah satu asmaul husna) tentang agama Islam kepada Novae melalui scrapbook. Scrapbook mampu menjadi media Novae untuk memahami makna kehidupan dengan berbagai paradoks kehidupan yang melatarbelakangi ditulisnya scrapbook. Tokoh Hipernova kemudian menjadi cahaya atau penerang (SEM; cahaya, cemerlang) jalan Novae untuk kembali memeluk agama Islam. Paradoks kehidupan ditunjukkan dengan adanya hubungan antitesis yang terbentuk pada kode simbolik (SYM: beragama berdasarkan keyakinan diri vs warisan), (ateis vs monoteis),(Berharap vs tidak berharap). Pengetahuan pada scrapbook mampu mengantarkan Novae pada sebuah titik untuk ahirnya percaya kepada Allah SWT. Novae kemudian mengucapkan dua kalimat syahadat (ACT: mengucap dua kalimat syahadat) dan mampu bertanggung jawab kepada keputusan yang dipilihnya. Novae kemudian menunjukkan tindakan dengan bersedekah (ACT: tindakan sedekah) kepada orang yang membutuhkan. Hal tersebut dilakukan sebagai bentuk kepatuhan Novae kepada Allah SWT.

Berdasarkan tanda dan penanda yang ada pada novel menunjukkan adanya aspek spiritual dalam diri Novae, yiatu hubungan transenden kepada Allah SWT ditunjukkan dengan mengikrarkan dua kalimat syahadat dilanjutkan dengan mengimani eksistensi Tuhan dan tetap menjalankan praksis religius hingga mampu menyadari pentingnya diri dalam kehidupan ini (spiritualitas) berikut dengan prinsip-prinsip hidupnya. Aspek spiritual 'idealisme' Novae saat ateis mampu mematahkan pernyataan atau asumsi sesorang akan spiritualisme ateisme. Pembahasan diatas mampu membantah pandangan masyarakat tentang agama bukan lagi tolak ukur tingkah laku pola manusia sebab selama menjadi ateis Novae memiliki idealisme diri yang kuat.

Penelitian ini masih banyak menyimpan celah untuk selanjutnya dapat dikaji dengan objek kajian yang sama atau topik kajian spiritualitas pada ateisme yang terdapat pada karya sastra lainnya. Metode yang digunakan pada penelitian ini bersifat konseptual, sehingga diperlukan adanya perluasan berupa penelitian pengembangan konsep kajian guna lebih mengetahui konsep spiritualitas secara menyeluruh. Penelitian selanjutnya 
diharapkan mampu membahas dan mengulas spiritualitas pada ateis lebih lanjut mengingat spiritualitas akan terus berkembang seiring berkembangnya masyarakat dan zaman.

\section{DAFTAR PUSTAKA}

Ahmad Pramudiyanto, Supana \& Muhammad Rohmadi. (2018). Karakteristik wong cilik pada wanda wayang kulit tokoh Panakawan. Humanus: Jurnal Ilmiah Ilmu-Ilmu Humaniora, 174-187.

Awaliyah, G. (2019, Mei Sabtu). Fenomena artis hijrah ubah wajah Islam di Indonesia. (R. Dwinanda, Producer, \& Republika.co.id) Retrieved from KHAZANAH: https://www.republika.co.id/berita/dunia-islam/islamnusantara/19/05/18/prolno414-fenomena-artis-hijrah-ubah-wajah-islam-diindonesia

Barthes, R. (1964). Elements of semiology (First Edit). United States, America: Eleventh Printing.

Barthes, R. (1991). Mythologies. New York, America: The Noonday Press.

Barthes, R. (2002). S/Z. United Kingdom: Blackwell.

Brzezinski, Z. (1993). Out of control: global turmoil on the eve of the twenty-first century. Collier Books.

Conttingham, J. (2005). The spiritual dimension. Cambridge, United Kingdom: Cambridge University Press.

Elkins, D. (1998). Towards a humanistic phenomenological spirituality: definition, description, and measurment. Humanistic Psychology.

Jabrohim. (2002). Sosiologi sastra beberapa konsep pengantar: metodologi penelitian sastra. Yogyakarta: PT. Hanindita dan Masyarakat Poetika.

Jabrohim. (2003). Metodologi penelitian sastra. Masyarakat Poetika Indonesia (Pradopo dkk, Ed.). Yogyakarta: Hanindita.

Jasmine, F. Auliya. (2018). Hipernova (S. Kamil, Ed.). Solo: Tinta Medina.

K, A. \&. (2010). A Study of 'Kenry' in Japanese and 'Hak' in Indonesian. Jurnal Humaniora, 22, 22-30.

Nelson, J. M. (2009). Psychology. Religion: Spirituality.

Newman, L. L. (2004). Faith, spirituality, and religion: a model for understanding the differences. The Collage of Students Affairs Journal, 23, No. 2, 106.

Piliang, Y. A. (2004). Semiotika teks : sebuah pendekatan analisis teks. Mediator, 5, No. 2, 189-198.

Pramudiyanto, A., Rohmadi, M., \& Supana. (2018). Characteristic of wong cilik on wayang kulit wanda of panakawan figures. Humanus, 17, 174-187.

https://doi.org/10.24036/humanus.v17i2.100683

Reid, A. (2008). Menuju sejarah Sumatra: antara Indonesia dan Dunia. Jakarta: Yayasan Obor.

Spencer, M. (2012). What is spirituality? A personal exploration. RC PSYCH: Royal Collageof Psychiatric, 1-4. 
Susilo, J. (2018). Seksualitas Vis A Vis spiritualitas dalam pesan kontras pornografi dan religiositas karya sastra (semiotika komunikasi Serat Centhini). Disertasi: Universitas Padjajaran.

Suhariyadi. (2014). Pengantar ilmu sastra: orientasi penelitian sastra. Lamongan: Pustaka Ilalang.

Widowati, \& Octaviani, R. (2016). Kajian novel bait-bait multazam karya Abidah El Khalieqy dengan pendekatan. Caraka, 3, No.1(4), 10.

Yuliani. (2018). Sistem kode dalam novel lelaki terakhir yang menangis di bumi karya M. Aan Mansyur (semiologi Roland Barthes). Skripsi: Universitas Negeri Makassar.

Yusdhiani, A. (2014). Spiritualitas dalam kumpulan cerpen lelaki yang membelah bulan karya Noviana Kusumawardhani. Skripsi: Airlangga University.

Yusuf, H. (2012). Eksistensi Tuhan dan agama dalam perspektif masyarakat kontemporer. Kalam: Jurnal Studi Agama Dan Pemikiran Islam, 6, No. 2.

Zacharek, S. (2008). The New York Times. Retrieved February 12, 2013, from The New York Times: http://www.nytimes.com/2008/04/27/books/review/Zachareck

Zuhriah. (2018). Makna warna dalam tradisi budaya; studi kontrastif antara budaya Indonesia dan budaya asing. Skripsi: Universitas Hasanuddin. 